\title{
US Naval Plans for War with the United Kingdom in the 1890s: A Compromise between Pragmatism and Theory
}

\section{Michael J. Crawford}

En 1890, Alfred Thayer Mahan a élaboré un plan de guerre en cas d'hostilités envers les Britanniques; pour leur part, les classes du Naval War College des États-Unis ont mis sur pied des plans semblables en 1894 et 1895. Ces plans portaient notamment sur le nord-est des États-Unis et sa frontière avec le Canada. Faisant partie des premiers exercices formels de planification de mesures de guerre de la marine américaine, ces plans représentent un compromis entre la nouvelle vision stratégique de la profession navale américaine et une conception pragmatique des limites de la flotte américaine.

In 1890, a small group of US naval professionals drew up plans for war in case of hostilities with the United Kingdom, and a few years later the Naval War College classes of 1894 and 1895, as their Problem in the Art of War, a new annual exercise, elaborated plans for war with the British. ${ }^{1}$ The plans that resulted from these efforts,

\footnotetext{
${ }^{1}$ Versions of this essay were delivered at "From Enemies to Allies: An International Conference on the War of 1812 and Its Aftermath," Annapolis, Maryland, 14 June 2013, and the 83rd annual meeting of the Society for Military History, in Ottawa, Ontario, 16 April 2016. The author thanks the commentators and audience at these conferences whose helpful comments contributed to revisions.

Ronald Spector, Professors of War: The Naval War College and the Development of the Naval Profession (Newport, R.I.: Naval War College Press, 1977), 71-73; Alfred Thayer Mahan, Contingency Plan of Operations in Case of War with Great Britain, December 1890, in Letters and Papers of Alfred Thayer Mahan, edited by Robert Seager and Doris Maguire, 3 vols. (Annapolis, MD: Naval Institute Press, 1997), 3: 559-76; Solution to the Problem of 1894, UNOpP, Record Group 12, Naval War College Archives, Newport, RI; Solution to the Problem of 1895, UNOpP, Record Group 12, Naval War College Archives, Newport, RI; United States, Department of the Navy, Annual Report of the Secretary of the Navy for the Year 1895 (Washington, DC:

Government Printing Office 1895), 169. For a summary of the problems and their solutions, see Naval War College, Abstract of Course (Washington: Government Printing Office, 1894), 29-31, and Naval War College, Abstract of Course (Washington: Government Printing Office, 1895), 2527. For brief modern analyses of these plans, see John B. Hattendorf, B. Mitchell Simpson, III, and John R. Wadleigh, Sailors and Scholars: The Centennial History of the Naval War College (Newport, RI: Naval War College Press, 1984), 40-43, and Steven T. Ross, American War Plans
}

The Northern Mariner/Le marin du nord, XXVI, No. 4 (Oct. 2016), 371-382. 
among the US Navy's first formal war planning exercises, represent a compromise between the new strategic vision of the American naval profession and a pragmatic understanding of the limitations of the US fleet.

Formal war planning, along with the establishment of war colleges and professional journals, was a feature of professionalization of the US Army and Navy. War planning allowed soldiers and sailors to apply theory to practical problems and thus improve their professional skills. As the army and navy pondered logical potential opponents, the United Kingdom came to the fore as the most dangerous potential enemy and took prominence in America's first professionally developed war plans. ${ }^{2}$

By 1890, besides the drive to professionalize, two major developments shaped the aspirations and vision of the US Navy's officer corps: the rise of US naval power and the development of a strategic outlook. The years 1889 and 1890 witnessed a series of events that historian Walter R. Herrick Jr., in his classic The American Naval Revolution, cites in identifying the period as marking "America's emergence as a great international power." In November 1889, the armoured cruiser Maine was launched; in May 1890, Alfred Thayer Mahan published his Influence of Sea Power upon History; in June Congress rescued the Naval War College from obscurity by returning it to Coaster's Harbor Island from its exile on Goat Island; and by the Navy Act of 1890 Congress endorsed continuing the project to build a modern battle fleet. ${ }^{3}$ James C. Rentfrow's recently published Home Squadron examines how the US Navy's officers envisioned themselves commanding battleships in a battle line and fighting fleet battles long before the vessels that could fulfill that vision ever existed. ${ }^{4}$

In conjunction with these developments, in 1890 Secretary of the Navy Benjamin F. Tracy appointed navy Captains Mahan and William Folger (chief of the Bureau of Ordnance) and Assistant Secretary of the Navy James Soley to a secret committee to produce plans for naval operations in case of war with various European powers, including France, Germany, Spain, and the United Kingdom. ${ }^{5}$ The committee began by preparing a plan for war with the United Kingdom,

1890-1939 (London and Portland, Oregon: Frank Cass, 2002), 8-9, 11.

2 On the context in which the United Kingdom was the chosen antagonist for these early exercises in war planning, see H. C. Allen, Great Britain and the United States: A History of AngloAmerican Relations (1783-1952) (New York: St. Martin's Press, 1955), 531-41; Kenneth Bourne, Britain and the Balance of Power in North America, 1815-1908 (Berkeley and Los Angeles: University of California Press, 1967), 352-412; Charles S. Campbell, From Revolution to Rapprochement: The United States and Great Britain, 1783-1900 (New York: John Wiley \& Sons, 1974), 175-89; Richard A. Preston, The Defence of the Undefended Border: Planning for War in North America 1867-1939 (Montreal: McGill - Queen's University Press, 1977), 227-28; Ross, American War Plans, ix, 145; and Arthur Campbell Turner, The Unique Partnership: Britain and the United States (New York: Pegasus, 1971), 51.

3 Walter R. Herrick Jr., The American Naval Revolution (Baton Rouge: Louisiana State University Press, 1966), 83.

${ }_{4}$ James C. Rentfrow, Home Squadron: The US Navy on the North Atlantic Station (Annapolis, MD: Naval Institute Press, 2014).

5 Herrick, The American Naval Revolution, 83. 
submitting the plan, which was mainly Mahan's handiwork, to the secretary in December $1890 .^{6}$

\section{The Study of Naval History and Theories of Sea Power}

The modern study of naval history and the attempt to use that study to understand strategic principles developed in the last decades of the nineteenth and first decades of the twentieth centuries. This was a period of intense economic rivalry between European states and of imperial expansion overseas. Belief that nations were in a struggle for survival, a struggle that required the mobilization of all of a nation's resources, including its intellectual resources, intensified international rivalries. Simultaneously, changes in the technology of naval warfare-steam power, steel hulls, rifled artillery, chemical propellants, torpedoes, and mines - raised questions about how naval wars were to be fought and what naval officers needed to know. Naval educators turned to history for answers, seeking to draw from the naval conflicts of the age of fighting sail and iron guns general principles useful for the age of steam and steel. The emergence of scientific, document-based historical studies in the universities in the latter half of the nineteenth century facilitated the writing of naval histories applicable to the education of naval officers. Between 1870 and 1914 naval history was integrated into the education of European and American naval officers. ${ }^{7}$

As a professor at the Naval War College, Alfred Thayer Mahan took part in this educational movement. Although his views were not unique, his book The Influence of Sea Power upon History produced the most notable influence on the public and on political leaders both domestically and abroad. ${ }^{8}$ Unsystematic in his explication of the principles of naval strategy, Mahan believed that the student best internalized an understanding of them through a study of historical examples. Because of this lack of system, one must derive Mahan's principles from his historical analyses. From army doctrine Mahan borrowed the following emphases: (1) The principle of concentration: the importance of concentrating force on a portion of the enemy's force while holding the other portions in check; (2) the strategic value of the central position and interior lines; and (3) the close relationship between logistics and combat.

The goal of naval warfare, according to Mahan, was command of the sea, which opened the sea lanes to your own commerce and enabled you to transport your armies where they were wanted, while depriving the enemy of the use of the sea. To

\footnotetext{
6 Mahan, Contingency Plan of Operations in Case of War with Great Britain, December 1890.

Richard Harding, Seapower and Naval Warfare, 1650-1830 (Annapolis, MD: Naval Institute Press, 1999), 1-11. On the formal teaching of naval history and strategy, see Andrew Lambert, The Foundations of Naval History: John Knox Laughton, the Royal Navy and the Historical Profession (London: Chatham Publishing, 1998).

8 Jon Sumida, Inventing Grand Strategy and Teaching Command: The Classic Works of Alfred Thayer Mahan Reconsidered (Baltimore: Johns Hopkins University Press, 1997) informs much of my understanding of Mahan's theories, discussed here and in the following five paragraphs.
} 


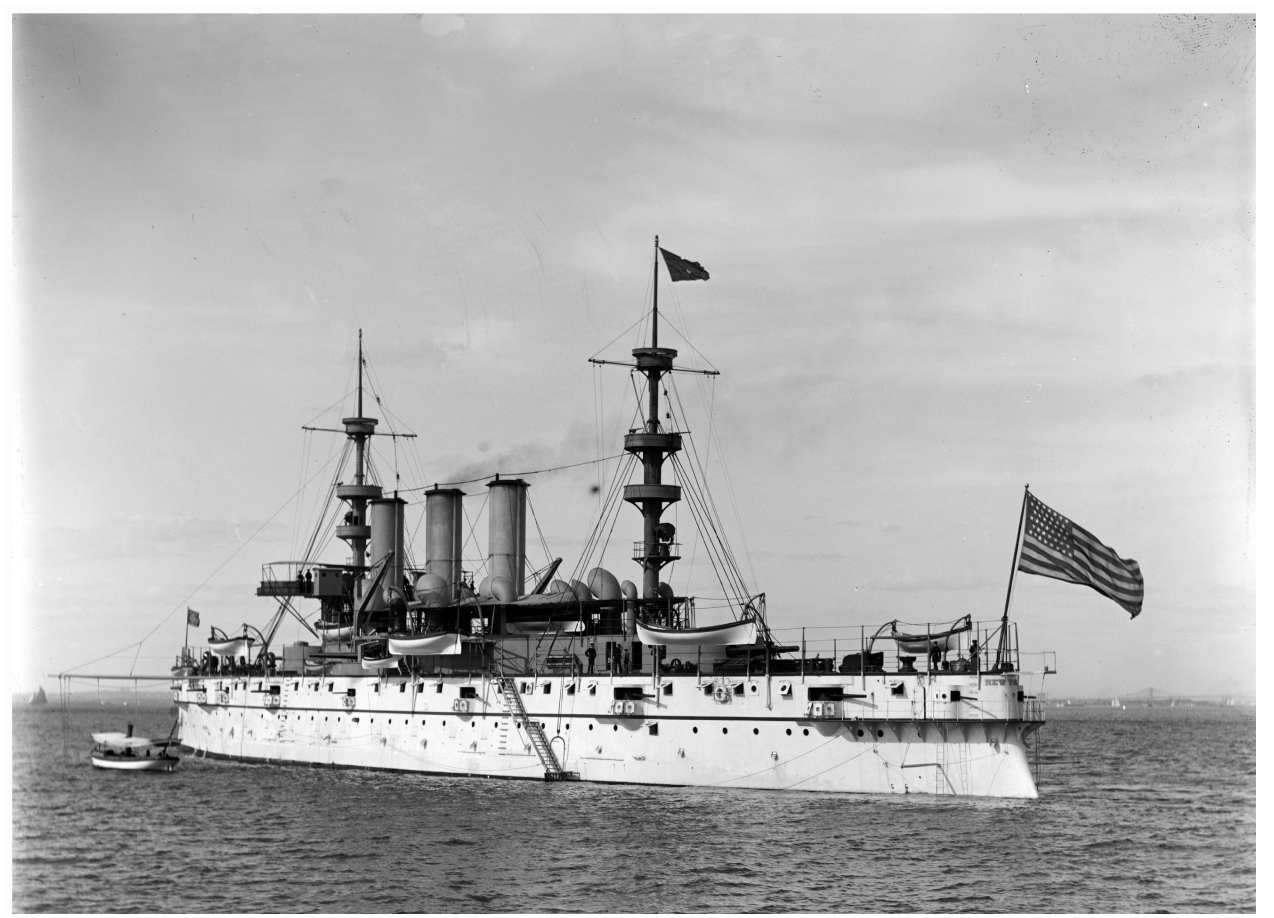

USS New York, armoured cruiser, commissioned in 1893. (Library of Congress)

achieve command of the sea, Mahan preached the decisive battle. The commander should bring together a superior force and engage the enemy, for to engage the enemy is the fleet's primary mission. To this principle, there are several corollaries. The offensive is preferable to the defensive. The fleet should consist principally of capital ships. The collective power of the entire fleet is more important than the power of the individual battleship, so to divide the fleet would be a cardinal sin. Mahan advised weaker navies to go on the offensive in order to provoke dispersion of the enemy's superior force.

Mahan downplayed the significance of cruising against the enemy's commerce. It was better to destroy or immobilize its naval forces. Winning command of the sea thereby would deny the sea to the enemy's commerce and ensure safety for friendly shipping. He recommended interdicting the enemy's trade by blockading ports, arguing that the beginning and ending points of a trade route were more favourable targets than the route itself. And he taught that convoys were an effective means of commerce protection.

Mahan disliked amphibious operations and small-craft coastal operations because they weakened the main fleet. He believed that ships were at a disadvantage against forts and disregarded "power projection from the sea." He recommended a limited number of bases of operation in order to reduce dispersing naval forces to protect them. 


\section{The War Plan of 1890}

When Mahan accepted the task of devising a war plan in the very year he published his first book articulating his strategic vision, theory ran up against reality: The weakness of the American fleet limited his ability to make his plan conform to his vision.

In 1890, the US fleet included only two armoured vessels rated above the third rate monitors, the second rate armoured cruiser Maine, which had been launched but not commissioned, and the second rate battleship Texas, which was still on the building ways. There were only five operational steel-hulled warships, with another seven building, launched, or fitting out. Mahan, nevertheless, assumed a naval force of twelve battleships, the number adequate for the defence of the nation's Atlantic coast according to Secretary Tracy's annual report. ${ }^{9}$ Mahan's plan was in a way a justification or a test of Tracy's call for a dozen battleships. How, then, did Mahan propose using the hypothetical naval force of the United States in a theoretical war with Britain?

Mahan reasoned that in case of hostilities between the United States and the United Kingdom, the US Navy, lacking sufficient ships as well as overseas coaling stations, would be unable to attack the British Isles. The belligerents, therefore, would of necessity meet in the Western Hemisphere. Even there, the British navy would be superior. The British would be unlikely to launch an amphibious invasion, but would attack harbours, bombard the US shoreline, and blockade parts of the coast. Their focus would be on the commercial centre of the United States, the East Coast between the Canadian boundary and the Chesapeake Bay. ${ }^{10}$

British interests in a war with the United States would include securing its North Atlantic trade, on which its survival depended. In North America, the Royal Navy retained two dockyards that could support its warships, one on the West Coast at Esquimalt, British Columbia, and the other at Halifax, Nova Scotia. Canadians, lacking a navy of their own, regarded the Royal Navy and its Canadian dockyards as their "strategic shield," primarily against the United States, whose military had invaded Canada in both the War of Independence and the War of 1812 and remained at the end of the nineteenth century the only power that could plausibly invade. ${ }^{11}$

Mahan posited that adequate fortification of harbors would free the US Navy to undertake offensive operations, which would require that the battle fleet be concentrated, in accordance with his doctrine that the

\footnotetext{
9 United States, Department of the Navy, Annual Report of the Secretary of the Navy for the Year 1895, 37; see also, Herrick, American Naval Revolution, 76.

10 This and the following six paragraphs analyze Mahan, Contingency Plan of Operations in Case of War with Great Britain, December 1890. See also A. T. Mahan, 1891 Plans of Operations in Case of War with Great Britain [n.p.: n.p., 1891?], typescript in the Navy Department Library (Washington, DC), which includes comments on the plan by Capt. D. H. Davis and Mahan's response to those comments. Mahan's comments are also printed in a letter to Charles H. Davis, 23 Dec. 1890, in Mahan, Letters and Papers, 2:35-37.

11 Roger Sarty, “A Navy of Necessity: Canadian Naval Forces, 1867-2014," The Northern Mariner/Le marin du nord 24:3\&4 (July and October 2014): 34-35.
} 
best defence for an inferior navy was offense. The American fleet should keep British naval forces on the East Coast occupied through harassment by cruisers and torpedo boats. These tactics would leave the enemy with three courses of action, each with a cost: increase its fleet in America, thus undermining its position in Europe; leave some positions unprotected; or disperse the fleet, thereby making detachments vulnerable to concentrated attack.

Given adequate time, the United States could, Mahan proposed, overrun Nova Scotia and occupy the enemy's only coalfield on the Atlantic coast. If the British were to lose either the naval base of Halifax or the coalfields, on which they depended for refuelling warships, they would have to base themselves on Bermuda. Colliers travelling to Bermuda would be within range and vulnerable to commerce raiders, whose reach was limited by coal capacity. Modifying his stance on commerce raiding, Mahan advocated putting all US vessels fast enough to be commerce raiders into operation in order to force the enemy to scatter its fleet to protect its commercial shipping. The scattered detachments would then be vulnerable to US attacks.

New York City would be the most eligible base for the hypothetical fleet of American battleships. The Brooklyn Navy Yard provided facilities for maintaining the fleet; the Hudson River offered a safe retreat in case of necessity; and the city's two watery entrances, Sandy Hook and Hell Gate, would force the British to station twenty-four ships there - twelve to block each entrance, to match the size of the US battle fleet - and perhaps an additional six ships to substitute for ships requiring resupply or repairs.

Mahan would station the US Navy's torpedo vessels at New London and in Narragansett Bay. From there, they would harass the flanks of the enemy squadron that blockaded the entrances to New York City. These attacks would be designed to wear down the enemy and help open Long Island Sound for American battle fleet sorties.

At the same time, US naval action would be needed to prevent a British naval assault on the United States by way of the St. Lawrence canals. This response required control of Lake Ontario and destruction of the canal system. The latter was the army's responsibility, but the US Marine Corps might be of assistance. Given the importance of Halifax to the British, the United States should be prepared on short notice to take advantage of any opportunity for its capture. Mahan was less worried about the Pacific Coast than the Atlantic because he believed the British would be at a disadvantage on the West Coast owing to sheer distance.

This, then, is the broad outline of Mahan's strategy for fighting a war against the superior British naval force: keep the battle fleet concentrated in order to take advantage of opportunities of attacking enemy detachments; use torpedo vessels to harass and wear down the enemy; employ commerce cruisers to force his dispersal; maintain mastery of Lake Ontario; and attack Halifax or the Atlantic coalfields as soon as possible. 


\section{The Naval War College's Problems in the Art of War of 1894 and 1895}

In 1894 the United States Naval War College, established in 1884 to promote the professional study of war among US naval officers, introduced a revised, sevenpart curriculum, one part of which was the annual war problem, a hypothetical war situation which the staff and students spent the four-month term, June through September, analysing. ${ }^{12}$ The war problems assigned for the years 1894 and 1895 were intended to develop detailed plans needed to put Mahan's strategy into effect, including an expedition against Canadian coalfields on the Atlantic coast that Mahan believed would cripple the Royal Navy's ability to operate in the theatre. ${ }^{13}$

Whereas Mahan's plan of 1890 postulated an American fleet of twelve battleships, the Naval War College's war problem of 1894 assumed a fleet of five battleships; and whereas Mahan's battleships were almost all hypothetical, the War College's battleships, if not all afloat and armed, had at least been authorized and were under construction. The class of 1894 revised Mahan's solution for a naval defence of the East Coast against a superior force. Mahan stationed the battle fleet in New York Harbor, from which it might sortie to Nantucket Sound, but the class of 1894 recommended stationing it in Nantucket Sound, where it would retain its mobility as well as threaten the British fleet's flank. While Mahan placed the torpedo flotilla in Narragansett Bay, the class of 1894 placed it in Gardiners Bay on Long Island, from which it could harass the enemy fleet threatening New York from Long Island Sound and from which it could retreat into Peconic Bay, which could be defended by land batteries. As an alternative, in case the battle fleet was forced to retreat, the class of 1894 followed Mahan in choosing New York Harbor for the battle fleet, where it would have access to facilities and the advantage of interior lines. ${ }^{14}$

After thus disposing of the main strategic issues of the exercise, the class of 1894 's solution deals with tactical formations and movements in various locations

\footnotetext{
12 The class of 1894 consisted of eighteen US naval officers, ensigns, lieutenants, and commanders, and two commanders in the Royal Swedish Navy. According to United States Naval War College, Register of Officers, 1884-1963, the class of 1895 consisted of twenty-five US naval officers, ensigns, lieutenants, commanders, and captains. In addition, the class apparently included two or three others: The biographer of Ellsworth Bertholf, of the US Revenue Cutter Service, states that Bertholf audited the course, which, in addition to the US naval officers, included an officer of the Rhode Island Naval Militia as well as an officer of the Royal Danish Navy. Hattendorf, et al., identify the Dane as a Captain Fritzer. The War College's Register of Officers, however, lists Fritzer with the Class of 1896. United States Naval War College, Register of Officers, 1884-1963 (Newport, R.I.: US Naval War College, 1963), 4-5; C. Douglas Kroll, Commodore Ellsworth Bertholf: First Commandant of the Coast Guard (Annapolis, MD.: Naval Institute Press, 2002), 2930; Hattendorf, Simpson, and Wadleigh, Sailors and Scholars, 42. For the new curriculum, see Hattendorf, et al., Sailors and Scholars, 39-43.

13 As Mahan was president of the Naval War College from 22 June 1886 to 12 January 1889 and again from 22 July 1892 to 10 May 1893, it is understandable that the war problems assigned for the years 1894 and 1895 were intended to develop detailed plans needed to put Mahan's strategy into effect.

14 This and the following three paragraphs are based on Solution to the Problem of 1894.
} 
where engagements with the enemy might take place, including New York Harbor, in Long Island Sound, and in Nantucket Sound. But the bulk of the solution addresses preparations to be made during the month between the declaration of war and the expected attack on the coast. The planning was practical, specific, and based on factual data, down to the locations and current staffing of coastal signal stations to the names, owners, and home ports of commercial vessels.

The solution to the 1894 problem devotes attention to the creation of a torpedo flotilla or "mosquito fleet." It identifies fifty steam yachts to be chartered and fitted with torpedo tubes and rapid-fire or machine guns and fifty large tugs to be reinforced for ramming and similarly armed. With the naval reserves reinforcing the battle fleet, the class of 1894 proposed a creative solution to the problem of recruiting the 2,500 sailors required for the mosquito fleet. The Lifesaving Service would be increased to twenty-five men at each of ten stations. Each station would supply the flotilla with seventeen men, accounting for 1,700 sailors. The balance of the flotilla men would be drawn from the longshoremen of New York City and other ports. The flotilla men would be a kind of naval fencibles, promised that they would serve only locally, and Congress would be asked to authorize prize money (presumably for the capture or destruction of enemy vessels) as a further inducement to serve.

The class of 1894 judged that the battle fleet would be significantly inferior to the British fleet. Therefore it had to avoid a major engagement into which the British might seek to draw it. The US fleet was to harass the enemy with feints and torpedoboat attacks and by diversions seek to induce the enemy to divide his fleet. In the meantime, scout vessels were to attack his seaborne commerce. The solution to the problem of 1894 also included an expedition against Halifax and the coalmines of the Pictou region.

The results of the summer's study of the war problem were not restricted simply to the creation of a war plan. From the study, as well as from associated war charts and war gaming, the college derived a list of practical conclusions, including, for example, that in a contest with a superior, invading fleet, the US Navy could not win a fleet battle in the open sea but must rather engage in bays, sounds, and interior waterways, where rams and torpedo boats would have tactical value. ${ }^{15}$

The Naval War College war problem for 1895 was similar to that of 1894, but instead of having New York as its objective, the enemy force intended to control the one hundred miles of New England coast between Casco Bay and Provincetown, and capture Portland or Boston, or both. The plan included a number of alternative courses of action depending on the movements of the enemy fleet and described preparations in elaborate detail. ${ }^{16}$

Captain Henry C. Taylor, president of the Naval War College from 1893 through 1896, noted in March of 1896 that the objects of the proposed naval strategy were the obstruction and delay of the enemy. Although the strategy was based on

\footnotetext{
Naval War College, Abstract of Course (Washington: Government Printing Office, 1894), 31.

16 Solution to the Problem of 1895.
} 


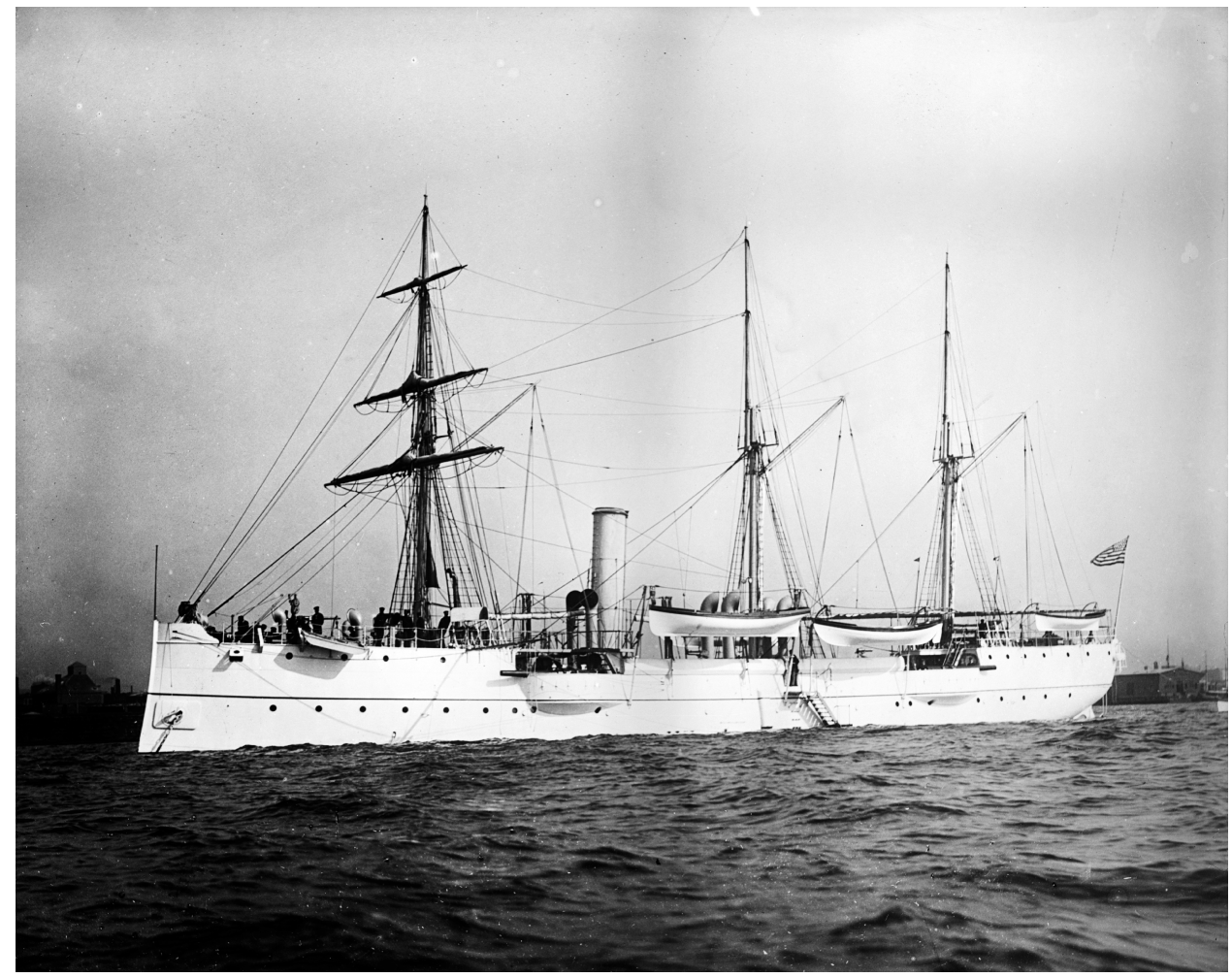

USS Petrel, Gunboat No. 2, 4th-rate gunboat commissioned in 1899. (Library of Congress)

necessity, given the limited naval forces the United States had at hand, Taylor observed, "our fleet will waste away under this system and presently be eliminated." In response to this inevitability, he outlined a plan for constructing additional warships after an outbreak of war. He envisioned building some fifty or sixty ships of from 2,500 to 3,000 tons, having armament powerful enough to penetrate battleships at close range and armour sufficient to withstand all but the heaviest guns. They were to be designed for speed and with coal capacity for operating at short ranges. He proposed having blueprints and building supplies prepositioned in protected shipyards along the East Coast so that in seventy-five days, while the existing fleet delayed the enemy, the new fleet would be ready to attack it. ${ }^{17}$

\section{The Origins of War Plan Red}

From the start of formal war planning in the United States in the 1890s, there was a certain political unreality to plans for war with the United Kingdom. The closest that such plans came to bearing fruit was the Venezuelan Crisis. In 1895, US

\footnotetext{
17 H. C. Taylor, "Outline of plan for construction of vessels after outbreak of war," UNOpP,
} Record Group 12, Naval War College Archives, Newport, RI. 
President Grover Cleveland invoked the Monroe Doctrine in favour of Venezuela in its boundary dispute with British Guiana, asserting that he would arbitrate the dispute and if necessary use force to impose his decision. That international crisis provided an element of seriousness to developing plans for hypothetical conflicts. Yet, diplomatic historians judge that after an initial outburst of jingoism, Cleveland's threat was bluster. Americans adopted the viewpoint of the British public, which was that war between the two democracies was "little less than unthinkable." $" 18$

Developments during the decade following the Venezuelan crisis transformed the relationship between the United Kingdom and the United States. The emergence of the US Navy as a world-class force played a role in bringing about what historians call the Great Rapprochement, for America's industrial and naval strength persuaded the British Admiralty that it would be better to accommodate the United States on issues not vital to British security and to have the United States as a friend rather than an antagonist. In 1895, however, both America's emergence as a marine giant and the Great Rapprochement lay in the future.

Mahan's 1890 plan and the solutions to the Naval War College war problems of 1894 and 1895, anticipated a plan, initiated shortly before the First World War and revised subsequently through the 1930s, for war with the United Kingdom known as Plan Red. ${ }^{19}$ In referencing Plan Red, the late British historian Jon Latimer misses the boat. In the final pages of his study of the War of 1812, Latimer discusses the legacies of that war. Among those legacies he finds an "enduring hostility to Britain and Canada within the US military," which, he says, "was finally extinguished only by the Second World War." As evidence of that hostility, he points to War Plan Red, a plan that included, like the American plans for the War of 1812, the invasion and conquest of Canada. Plan Red, writes Latimer, was no academic exercise, but was "detailed, amended and acted upon." ${ }^{20}$ Historians who have closely examined planning for war between the United Kingdom and Canada on the one side and the United States on the other, including Richard A. Preston - on whom Latimer relies - differ with Latimer. Their interpretations suggest that Latimer exaggerates the significance of Plan Red. Preston argues that in the United States war planning was divorced from political reality. ${ }^{21}$ Steven Ross,

\footnotetext{
18 Allen, Great Britain and the United States, 531-41, quote from 541; Campbell, From Revolution to Rapprochement, 175-89.

19 For a description of a war game based on War Plan Red played at the Army War College during the 1911-1912 academic year, see John B. Hattendorf, "Commonwealth Navies as Seen by the United States Navy, 1910-2010," in The Northern Mariner/Le marin du nord 24: 3\&4 (July and October 2014), 161-62.

20 Jon Latimer, 1812: War with America (Cambridge, MA: Harvard University Press, 2007), 4078

21 Preston, The Defence of the Undefended Border, 227-28. "Professional soldiers had to plan with inadequate support, inadequate direction, and inadequate understanding of political realities." In fact, "in the two decades between the World Wars, planning for wars in North America had ... been unrelated to the political reality of international relations. . . . War planners were without influence ... . no real attempt was made to relate [war] planning to foreign policy." "American
} 
of the US Naval War College, agrees with Preston that the more elaborate and definitive US plans for fighting a war with the British by invading Canada became, the more divorced from reality they grew. ${ }^{22}$ Later, in the years between the world wars, US Army and Navy planners simply assumed that America's commercial competition with the British would inevitably lead to war, ${ }^{23}$ and tensions arising from "naval rivalry, war debts, and arguments over belligerent versus neutral rights" justified both American and British strategists making contingency plans, even though relations between their two countries remained cordial and the possibility of war between them remote. ${ }^{24}$ After the London Naval Treaty of 1930, US naval strategists considered the British battle fleet inferior to America's and thereafter the navy's War Plans Division omitted the British as a possible enemy from its annual estimates. During the 1930s, the United States Army continued to plan for war with the United Kingdom, not because there was any reasonable expectation of such a conflict, but because it was the best way the army knew of justifying its procurement plans. $^{25}$

Plan Red did not result from a longstanding hostility within the US military against the British dating to the War of 1812. Rather, it reflected the rise of war planning as part of the military professionalization movement of the late nineteenth century and the isolation of such war planning from foreign policy. Even as the Great Rapprochement that began after the Spanish American War gained in strength and permanence, US plans for fighting the British remained a part of the repertory of exercises, and, despite the transformation of the balance of naval forces in the decades running up to the Second World War, the basic outlines of the American plans remained intact: Plan Red continued to rest on a military campaign in eastern Canada, including capture of Halifax, combined with a defensive posture along the Atlantic coast. Similarly, even after British statesmen, in the wake of the 1895 Venezuelan crisis, accepted "the thesis that war with the United States was simply

\footnotetext{
planning for war with Canada was ... inconsequential in the early 1930s."

22 "War planning in the United States included exploration of strategy for a war with Britain —and so with Canada - which was an anachronistic vestige of older concerns. At about the time that the Japanese invasion of Manchuria in 1931 was reducing the possibility of British collaboration with Japan against the United States to its lowest point, the war planning machinery in the United States finally cranked out its most developed plan for war with Britain." Ibid., 228. See also, Ross, American War Plans 1890-1939: "The probabilities of such wars were at best remote. . . Plans for a major war were at best training exercises designed to familiarize officers with the range of problems associated with a major conflict" (xi); "Plan Red lacked a serious political rationale. The idea that the United States and the British Empire would engage in a massive conflict against each other because of trade disputes was at best remote" (145). Ray S. Cline is in accord with this judgment, Washington Command Post: The Operations Division (Washington, DC: Office of the Chief of Military History, Dept. of the Army, 1951), 35-36.

23 William R. Braisted, "On the American Red and Red-Orange Plans, 1919-1939," in Naval Warfare in the Twentieth Century 1900-1945, edited by Gerald Jordan (London: Croom Helm, 1977), 167-85.

${ }^{24}$ Christopher M. Bell, "Thinking the Unthinkable: British and American Naval Strategies for an Anglo-American War, 1918-1931," International History Review 19 (1997): 789-1008, 791.

25 Braisted, "On the American Red and Red-Orange Plans," 180-81.
} 
not a possible policy, ${ }^{, 26}$ British military men continued to make contingency plans for such a war. ${ }^{27}$

\section{Conclusions}

The backwardness of the US Navy in the early 1890s shaped the era's war plans. The inferior size of the United States Navy made the Atlantic coast vulnerable to seaborne attack by a major European navy. It is remarkable the extent to which US plans in the 1890s for war with the United Kingdom relied on converted commercial vessels to serve as commerce raiders, torpedo boats, rams, and gun vessels, on Lake Ontario, on the Atlantic coast, and on the high seas. The United States looked to merchant mariners to man the expanded fleet, even turning to longshoremen. And the government saw prize money as an incentive for men to serve. In the navy's war plans in the early 1890s, the retrograde status of America's weapons technology is striking. It included steam yachts fitted with spar torpedoes, tugboats fitted with iron rams, and commerce raiders cruising under sails.

Since most records of the army's war plans for the period are unavailable, ${ }^{28}$ the navy's plans for fighting a war with the British developed by Captain Alfred Thayer Mahan in 1890 and elaborated in the Naval War College War Problems four and five years later are the best windows on the United States' strategic thinking at this time, before the emergence of the United States as a major naval power. In the mid1890s, the Royal Navy was the world's most powerful, while the US Navy was only in the beginning stages of building a modern fleet. The process of modernization, although begun in the 1880s, was still little advanced by 1895 . Among its ships, the US Navy possessed only two battleships (Texas and Indiana), two armoured cruisers (Maine and New York), and two torpedo boats. Although Mahan postulated a battle fleet of twelve ships, his plan as well as the Naval War College problems of 1894 and 1895 conceived of the navy as a coastal defence force whose aim was not to confront the enemy's superior fleet in decisive battle, but to fight a war of delay and attrition, awaiting opportunities to nip at the invader.

\footnotetext{
${ }^{26}$ Bourne, Britain and the Balance of Power in North America, 352-412; Turner, The Unique Partnership, 51.

27 Bourne, Britain and the Balance of Power in North America, 313-401; Preston, The Defence of the Undefended Border, 125-233. As Preston observes, "improved war-planning capability, ... in both Britain and the United States, produced increased planning for war in North America when the likelihood of such a war was declining. Increased capacity for war-planning activity on both sides did not make war more possible or more likely." The Defence of the Undefended Border, 7. Even Christopher M. Bell, who argues for a greater significance for Plan Red, sees that significance in its availability as "a window into the strategic mind of the US navy," not as a plan with serious potential. Bell, "Thinking the Unthinkable," 791.

${ }_{28}$ Bourne, Britain and the Balance of Power in North America, 319.
} 